\title{
Factors Associated With Pulmonary Tuberculosis- HIV Co-Infection in Treatment-Naive Adults in Jos, North Central Nigeria
}

\section{Citation}

Agbaji O, Ebonyi AO, Meloni ST, Anejo-Okopi JA, Akanbi MO, et al. 2013. Factors Associated With Pulmonary Tuberculosis-HIV Co-Infection in Treatment- Naive Adults in Jos, North Central Nigeria. J AIDS Clin Res 4: 222. doi:10.4172/2155-6113.1000222

\section{Published Version}

doi:10.4172/2155-6113.1000222

\section{Permanent link}

http://nrs.harvard.edu/urn-3:HUL.InstRepos:28724491

\section{Terms of Use}

This article was downloaded from Harvard University's DASH repository, and is made available under the terms and conditions applicable to Other Posted Material, as set forth at http:// nrs.harvard.edu/urn-3:HUL.InstRepos:dash.current.terms-of-use\#LAA

\section{Share Your Story}

The Harvard community has made this article openly available.

Please share how this access benefits you. Submit a story.

\section{Accessibility}




\title{
Factors Associated With Pulmonary Tuberculosis-HIV Co-Infection in Treatment-Naive Adults in Jos, North Central Nigeria
}

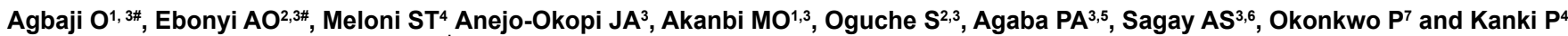

${ }^{1}$ Department of Medicine, University of Jos/ Jos University Teaching Hospital, Jos. Nigeria

${ }^{2}$ Department of Paediatrics, University of Jos/ Jos University Teaching Hospital, Jos, Nigeria

${ }^{3}$ AIDS Prevention Initiative in Nigeria (APIN), Jos University Teaching Hospital, Jos, Nigeria

${ }^{4}$ Department of Immunology and Infectious Diseases, Harvard School of Public Health, Boston, MA, USA

${ }^{5}$ Department of Family Medicine, University of Jos/ Jos University Teaching Hospital, Jos, Nigeria

${ }^{6}$ Department of Obstetrics and Gynaecology, University of Jos/ Jos University Teaching Hospital, Jos, Nigeria

${ }^{7} A I D S$ Prevention Initiative in Nigeria (APIN) Ltd GTE, Abuja, Nigeria

"Contributed equally and share first authorship

\begin{abstract}
Background: Co-infection with tuberculosis and human immunodeficiency virus (TB-HIV) remains a major global health problem, with about 1.1 million new cases of TB in HIV-positive persons reported in $2011 ; 79 \%$ of the reported cases were amongst patients living in Africa. Advanced immune suppression remains the most important risk factor for tuberculosis in those with HIV, but epidemiological and clinical factors have also been identified. We sought to determine the prevalence and factors associated with pulmonary tuberculosis (PTB) in antiretroviral therapy (ART)naive HIV-infected patients seeking HIV care services at a tertiary health facility in North Central Nigeria.

Methods: We compared clinical and laboratory data for $218 \mathrm{HIV}-1$ positive adults with and without a diagnosis of pulmonary tuberculosis. Results from univariate analyses informed the selection of predictors to conduct multivariate analysis to determine which factors were associated with presence of PTB-HIV co-infection.

Results: The prevalence of PTB-HIV co-infection in the evaluated cohort was $9.6 \%$. Lower CD4+ cell count and the presence of oropharyngeal candidiasis were independently associated with PTB-HIV co-infection. CD4+ cell count was strongly associated with PTB-HIV co-infection $(p=0.002)$ with the odds of co-infection reduced by $85 \%$ in those with a CD4+ cell count $>100$ cells $/ \mathrm{mm}^{3}$ compared to those with $<100 \mathrm{cells} / \mathrm{mm}^{3}$. There was a strong association between oropharyngeal candidiasis and PTB-HIV co-infection, where the odds of co-infection are about 4.5 times higher in those with oropharyngeal candidiasis than those without candidiasis $(p=0.008)$.

Conclusion: PTB was prevalent among HIV patients seeking care in our setting. Severe immune suppression and oropharyngeal candidiasis were associated with PTB-HIV co-infection in our patients at presentation. Potential implications for severe immune suppression and advanced HIV disease are a poor clinical outcome and further spread of PTB. Strategies to encourage the early diagnosis of both HIV and TB should be considered.
\end{abstract}

Keywords: PTB-HIV Co-infection; Immune suppression; CD4+ cell count; Oropharyngeal candidiasis

\section{Introduction}

Human immunodeficiency virus (HIV) infection continues to be a major global health problem; a 2011 estimate indicates that 23.5 million people living with HIV resided in sub-Saharan Africa, which represents $69 \%$ of the global HIV burden [1]. Also in 2011, 8.7 million people became ill with tuberculosis (TB) of which 1.4 million died [2]. There were about 1.1 million new cases of HIV-positive new TB cases with $79 \%$ of them living in Africa and globally about 430,000 people died of HIV-associated TB [2].

Advanced immune suppression remains the most important risk factor for tuberculosis in those with HIV [3], but epidemiological and clinical factors have also been identified [4,5]. We previously evaluated risk factors for TB in our population of adult patients on antiretroviral therapy (ART) and noted that poor immunologic and/or virologic response to ART and male sex were some of the risk factors for TB in ART patients [6]. However, we do not know if such risk factors differ in pre-ART patients.

Pulmonary tuberculosis (PTB) is predominantly responsible for TB transmission in human populations $[7,8]$. Prevalence and known risk factors for PTB among HIV-infected adults vary from one setting to another $[5,9,10]$. Identification of the factors associated with PTB-
HIV co-infection in pre-ART HIV patients could have implications for clinical management and TB control strategies.

In this study, we determined the factors associated with PTB coinfection in a cohort of ART-naive HIV-infected patients presenting to the AIDS Prevention Initiative in Nigeria (APIN)-supported HIV clinic at the Jos University Teaching Hospital (JUTH), Jos.

\section{Methods}

\section{Study setting/population}

The study was carried out at the HIV clinic at the Jos University Teaching Hospital, Jos; the care and treatment program has been

*Corresponding author: Phyllis Kanki, Department of Immunology and Infectious Diseases, Harvard School of Public Health, 651 Huntington Avenue, Boston, MA USA, E-mail: pkanki@hsph.harvard.edu

Received June 18, 2013; Accepted July 19, 2013; Published July 25, 2013

Citation: Agbaji O, Ebonyi AO, Meloni ST, Anejo-Okopi JA, Akanbi MO, et al. (2013) Factors Associated With Pulmonary Tuberculosis-HIV Co-Infection in TreatmentNaive Adults in Jos, North Central Nigeria. J AIDS Clin Res 4: 222. doi: 10.4172/2155 6113.1000222

Copyright: ( 2013 Agbaji O, et al. This is an open-access article distributed unde the terms of the Creative Commons Attribution License, which permits unrestricted use, distribution, and reproduction in any medium, provided the original author and source are credited. 
supported by the U.S. President's Emergency Plan for AIDS Relief (PEFPAR) since 2004. This clinic provides comprehensive HIV care services for the city of Jos, which is located in Jos North Local Government Area (LGA) of Plateau State. The clinic also serves as a referral centre for health facilities in other LGAs of the state and even other states in the region. In a 2006 census, the population of Plateau State was 3,206,531, with the capital city of Jos having a population of approximately 900,000. All HIV-related clinic, pharmacy and laboratory data for the enrolled patients are maintained in electronic databases at the site.

\section{Study design}

This was a cross-sectional study in which data on 218 consecutive adult patients ( $\geq 15$ years) accessing care at the adult ART clinic over a 7-month period from October 2010 - April 2011 were evaluated. All patients included in the study provided written informed consent for the use of their data for research as approved by the institutional review boards at the Jos University Teaching Hospital, APIN Ltd. and Harvard School of Public Health. Patients who were on TB treatment prior to presentation were excluded from the study. All newly diagnosed HIVinfected persons initiating care in the clinic were routinely screened for TB using symptoms and chest radiographs. Those with chronic cough ( $\geq 2$ weeks), in addition had sputum smear microscopy using ZiehlNeelsen (Z-N) stain for the Mycobacterium tuberculosis (Mtb) acid-fast bacilli (AFB). Other radiologic and histologic tests were carried out where indicated. Culture and molecular diagnostic facilities for $\mathrm{TB}$ were not available at the time of this study. The analyses utilized data that were already being captured in an electronic data management system as a part of ongoing Harvard/APIN PEPFAR Program. The data accessed for the 218 subjects included: demographic (age, sex, residence, education level, occupation, marital status, mode of HIV transmission, spouse HIV status, spouse ARV treatment status), clinical (WHO HIV clinical stage, oropharyngeal candidiasis, chronic diarrhoea and Kaposi's sarcoma (KS)) and laboratory (hepatitis b virus (HBV) status, viral load and CD4 cell count) variables.

All laboratory tests were done as a part of the existing treatment program; no additional laboratory analyses were done for the purposes of the analyses described here. HIV serodiagnosis was conducted using two different rapid HIV tests: Uni-Gold (Trinity Biotech Plc Bray Co Wicklow, Ireland) and Determine HIV-1/2 test (Determine Alere Medical Co., Ltd 357 Matsuhidai, Japan). CD4+ lymphocyte count was measured by flow cytometry (Partec GmbH, Munster Germany) and HIV-1 RNA viral load was measured using the Roche Cobas Amplicor HIV-1 Monitor, version 1.5 (Roche Diagnostics GmbH, Mannheim, Germany). HBsAg was determined using Enzyme Immunoassay (EIA) (Monolisa HBsAg Ultra3; Bio-Rad).

\section{Case definitions}

In our study, all patients with positive sputum AFB smears were classified as having PTB. In persons with negative AFB smears, a diagnosis of smear negative PTB was made in line with the World Health Organization's recommendation if a TB suspect had a chest radiograph consistent with PTB [11]. A patient with both PTB and HIV at the time of care was considered a case of PTB-HIV co-infection.

\section{Statistical methods}

All of the analyses were performed using Stata software version 10.1 (Stata Corporation, College Station, Texas, USA). Univariate associations of each independent variable with PTB-HIV co-infection were examined using the Fisher's exact test for categorical variables and the Wilcoxon signed rank test for continuous variables, as these variables were not normally distributed. In the univariate analysis, the continuous variables were categorized as follows: age into four groups based on quartile distribution; CD4+ cell count into four groups (based on clinical relevance and also using the WHO cut-off value of 200 cells/ $\mathrm{mm}^{3}$ [3]); and, RNA viral load into 3 groups based on clinical relevance and $\log$ categories. All tests were two-sided and a p-value of 0.05 was considered significant.

Following the results of the univariate analyses, the following predictor variables were further stratified: age $(\leq 34$ years versus $>34$ years), education level, marital status, WHO clinical stage (stage 3 or 4 versus stages 1 or 2 ) HIV RNA viral load ( $<5.0$ versus $\geq 5 \log _{10}$ copies/ $\mathrm{mL})$ and CD4+ cell count $(\leq 100$ cells $/ \mathrm{mL}$ versus $>100$ cells $/ \mathrm{mL})$. We used 34 years cut-off for stratifying age into two groups as that was the median value for the age variable. And for the CD4 count variable, the 100 cells $/ \mathrm{mL}$ value was the point at which we saw the main difference. We had previously left the 3 categories and found that leaving it as 3 categories took away from the strength of the final model and that using the 100 cells $/ \mathrm{mL}$ cut-off made it a stronger predictor variable. Thus, collapsing the age and CD4 count variables subsequently gave us a more parsimonious model with fewer degrees of freedom.

Univariate and multivariate logistic regression models were fitted to determine the factors associated with PTB-HIV co-infection, which were expressed as an odds ratio. Variables were considered for inclusion in the multivariate model if they were found associated with the risk of co-infection in the univariate analyses at $p<0.20$. Sex and age were included a priori in the multivariate model since many disease processes, including PTB and HIV, are often influenced by age and sex. A backward stepwise modelling strategy was used in building the final multivariate model. The area under the receiver operating characteristic (ROC) curve was also determined to assess the performance of our model.

\section{Results}

Of the $218 \mathrm{HIV}-1$ infected adult patients, 21 (9.6\%) had PTBHIV co-infection. In the cohort, a majority (60.1\%) were females, in the younger ( $<35$ years) age group $(50.9 \%)$, residents of Plateau State (64.7\%), had secondary level education or greater $(67.9 \%)$, were employed (76.1\%) and married (65.6\%). In the cohort, $47.2 \%$ had an HIV-positive spouse, and $10.1 \%$ of those spouses were on ARV drugs. The predominant mode of transmission was heterosexual sex (97.7\%). At the time of presentation, $56.3 \%$ of subjects were diagnosed as being WHO clinical stage 3 or $4,6.4 \%$ had HBV co-infection, $20.6 \%$ had oropharyngeal candidiasis, $16.1 \%$ had chronic diarrhoea and $3.7 \%$ had Kaposi's sarcoma.

In univariate analyses, patients with HIV-PTB co-infection were more likely than those with HIV mono-infection to be diagnosed with WHO stage $4(61.9 \%$ vs. $18.0 \%$; $\mathrm{p}<0.001)$ be HBV positive $(19.1 \%$ vs. $5.1 \%$; $=0.03)$; have oropharyngeal candidiasis $(52.4 \%$ vs $17.3 \%$; $\mathrm{p}=0.001)$; and, report chronic diarrhoea $(42.9 \%$ vs. $13.2 \%$; $\mathrm{p}=0.002)$. The median HIV viral load was higher in those with PTB co-infection compared to those with HIV alone (5.0 $\log _{10}$ copies/mL (4.4-6.0) versus $4.6 \log _{10}$ copies/mL (4.2-5.0); $\mathrm{p}=0.03$ ). The median $\mathrm{CD} 4+$ cell count was significantly lower in those with $\mathrm{PTB}$ co-infection compared to those with HIV alone (53 cells/mL (IQR: $31-93$ ) versus 201 cells/mL (IQR: $115-291) ; \mathrm{p}<0.0001)$. There were no subjects $(0.0 \%)$ with PTB-HIV coinfection with a CD4+cell count above the cut-off level $\left(200 / \mathrm{mm}^{3}\right)$ for severe immune suppression (Table 1). 


\begin{tabular}{|c|c|c|c|c|}
\hline \multirow[t]{2}{*}{ Characteristics } & Total & $\begin{array}{l}\text { PTB-HIV co- } \\
\text { infection }\end{array}$ & $\begin{array}{l}\text { HIV mono- } \\
\text { infection }\end{array}$ & P value $^{*}$ \\
\hline & N (\%) & $\mathbf{N}(\%)$ & N (\%) & \\
\hline $\begin{array}{l}\text { Age (yrs) } \\
\quad<29 \\
29-34 \\
35-41 \\
>41 \\
\quad \text { Median (IQR) }\end{array}$ & $\begin{array}{l}56(25.7) \\
55(25.2) \\
56(25.7) \\
51(23.4) \\
34(28-41)\end{array}$ & $\begin{array}{c}5(23.8) \\
6(28.6) \\
5(23.8) \\
5(23.8) \\
34(28-41)\end{array}$ & $\begin{array}{l}51(25.9) \\
49(24.9) \\
51(25.9) \\
46(23.3) \\
34(29-41)\end{array}$ & $0.96^{* *}$ \\
\hline $\begin{array}{l}\text { Sex } \\
\text { Male } \\
\text { Female }\end{array}$ & $\begin{array}{c}87(39.9) \\
131(60.1)\end{array}$ & $\begin{array}{c}12(51.7) \\
9(42.9)\end{array}$ & $\begin{array}{c}75(38.1) \\
122(61.9)\end{array}$ & 0.10 \\
\hline $\begin{array}{l}\text { Residence } \\
\text { Plateau } \\
\text { Others }\end{array}$ & $\begin{array}{c}141(64.7) \\
77(35.3)\end{array}$ & $\begin{array}{c}16(76.2) \\
5(23.8)\end{array}$ & $\begin{array}{c}125(63.5) \\
72(36.6)\end{array}$ & 0.34 \\
\hline $\begin{array}{l}\text { Education level } \\
\text { None } \\
\text { Primary } \\
\text { Secondary } \\
\text { Tertiary }\end{array}$ & $\begin{array}{l}21(9.6) \\
49(22.5) \\
79(36.2) \\
69(31.7)\end{array}$ & $\begin{array}{l}0(0.0) \\
6(28.6) \\
6(28.6) \\
9(42.8)\end{array}$ & & 0.27 \\
\hline $\begin{array}{l}\text { Occupation } \\
\text { Student } \\
\text { Unemployed } \\
\text { Employed }\end{array}$ & $\begin{array}{c}19(8.6) \\
30(15.2) \\
150(76.1)\end{array}$ & $\begin{array}{c}2(9.5) \\
1(4.8) \\
18(85.7)\end{array}$ & $\begin{array}{c}17(18.6) \\
30(15.2) \\
150(76.1)\end{array}$ & 0.51 \\
\hline $\begin{array}{l}\text { Marital status } \\
\text { Married } \\
\text { Widowed } \\
\text { Divorced/ Separated } \\
\text { Single }\end{array}$ & $\begin{array}{c}143(65.6) \\
16(7.3) \\
15(6.9) \\
44(20.2)\end{array}$ & $\begin{array}{c}14(66.7) \\
2(9.5) \\
0(0.0) \\
5(23.8)\end{array}$ & $\begin{array}{c}129(65.5) \\
14(7.1) \\
15(7.6) \\
39(19.8)\end{array}$ & 0.66 \\
\hline $\begin{array}{l}\text { Spouse HIV status } \\
\text { Positive } \\
\text { Negative }\end{array}$ & & & & 0.17 \\
\hline $\begin{array}{l}\text { Spouse on ARV drugs } \\
\text { On ARV } \\
\text { Not on ARV }\end{array}$ & & $\begin{array}{c}0(0.0) \\
21(100.0)\end{array}$ & & 0.14 \\
\hline $\begin{array}{l}\text { Mode of HIV transmission } \\
\text { Heterosexual } \\
\text { Blood transfusion }\end{array}$ & $\begin{array}{c}213(97.7) \\
5(2.3)\end{array}$ & $\begin{array}{c}20(95.2) \\
1(4.8)\end{array}$ & $\begin{array}{c}193(98.0) \\
4(2.0)\end{array}$ & 0.40 \\
\hline $\begin{array}{c}\text { WHO clinical stage } \\
1 \\
2 \\
3 \\
4\end{array}$ & $\begin{array}{l}39(19.6) \\
48(24.1) \\
67(33.7) \\
45(22.6)\end{array}$ & $\begin{array}{c}0(0.0) \\
2(9.5) \\
6(28.6) \\
13(61.9)\end{array}$ & $\begin{array}{l}39(21.9) \\
46(25.8) \\
61(34.3) \\
32(18.0)\end{array}$ & $<0.001$ \\
\hline $\begin{array}{l}\text { HBV status } \\
\text { Positive } \\
\text { Negative }\end{array}$ & $\begin{array}{c}14(6.4) \\
204(93.6)\end{array}$ & $\begin{array}{c}4(19.1) \\
17(80.9)\end{array}$ & $\begin{array}{c}10(5.1) \\
187(94.9)\end{array}$ & 0.03 \\
\hline $\begin{array}{l}\text { Oropharyngeal candidias } \\
\text { Present } \\
\text { Absent }\end{array}$ & $\begin{array}{c}45(20.6) \\
173(79.4)\end{array}$ & $\begin{array}{l}11(52.4) \\
10(47.6)\end{array}$ & $\begin{array}{c}34(17.3) \\
163(82.7)\end{array}$ & 0.001 \\
\hline $\begin{array}{l}\text { Chronic diarrhoea } \\
\text { Present } \\
\text { Absent }\end{array}$ & $\begin{array}{c}35(16.1) \\
183(83.9)\end{array}$ & $\begin{array}{c}9(42.9) \\
12(57.1)\end{array}$ & $\begin{array}{c}26(13.2) \\
171(86.8)\end{array}$ & 0.002 \\
\hline $\begin{array}{l}\text { Kaposi's sarcoma } \\
\text { Present } \\
\text { Absent }\end{array}$ & $\begin{array}{c}8(3.7) \\
210(96.3)\end{array}$ & $\begin{array}{c}1(4.8) \\
20(95.2)\end{array}$ & $\begin{array}{c}7(3.5) \\
190(95.5)\end{array}$ & 0.56 \\
\hline $\begin{array}{l}\text { HIV RNA Log viral load } \\
\text { (copies /ml) } \\
<4.0 \\
4.0-4.9 \\
\geq 5.0 \\
\text { Median (IQR) }\end{array}$ & $\begin{array}{c}31(14.2) \\
122(56.0) \\
65(29.8) \\
4.6(4.2-5.0)\end{array}$ & $\begin{array}{c}2(9.5) \\
8(38.1) \\
11(52.4) \\
5.0(4.4-6.0)\end{array}$ & $\begin{array}{c}29(14.7) \\
114(57.9) \\
54(27.4) \\
4.6(4.2-5.0)\end{array}$ & 0.03 \\
\hline $\begin{array}{l}\left.\text { CD4 count (per } \mathbf{m m}^{3}\right) \\
\geq 5.0 \\
51-100 \\
101-200 \\
>200 \\
\quad \text { Median (IQR) }\end{array}$ & $\begin{array}{c}30(13.8) \\
29(13.3) \\
60(27.5) \\
99(45.4) \\
185(92-280)\end{array}$ & $\begin{array}{c}10(47.6) \\
6(28.6) \\
5(23.8) \\
0(0.0) \\
53(31-93)\end{array}$ & $\begin{array}{c}20(10.2) \\
23(11.7) \\
55(27.9) \\
99(50.2) \\
201(115-291)\end{array}$ & $<0.001$ \\
\hline
\end{tabular}

*Fisher's exact test for the association between categorical variables and PTB-HIV co-infection [20]

**Wilcoxon rank sum test for comparison of median values

Table 1: Characteristics of Adults Initiating HIV Care at JUTH by PTB-HIV Coinfection Status.
In the unadjusted logistic regression analyses, WHO HIV clinical stage $3 / 4$, HBV positivity, presence of oropharyngeal candidiasis and chronic diarrhoea were all significantly associated with PTB-HIV coinfection (OR: 8.68, 4.4, 5.27 and 4.93, respectively). The odds of having PTB-HIV co-infection was 2.91 times more in those with HIV RNA viral load of $\geq 5.0 \log _{10} \mathrm{cp} / \mathrm{mL}$ as compared to those with less $(\mathrm{p}=0.02)$ while the odds of having PTB-HIV co-infection was 9\% lower in those with CD4+ cell counts $>100$ cells $/ \mathrm{mL}$ as compared to those with $\leq 100$ cells $/ \mathrm{mL}(\mathrm{p}<0.001)$ (Table 2$)$.

In the multivariate analyses, CD4+ cell count was significantly associated $(\mathrm{p}=0.002)$ with PTB-HIV co-infection, with the odds of co-infection reduced by $85 \%$ in those with a count $>100$ cells $/ \mathrm{mm}^{3}$ compared to those with a count $<100$ cells $/ \mathrm{mm}^{3}$. In addition, patients with oropharyngeal candidiasis were found to be nearly 4.5 times more likely to have PTB-HIV co-infection than those without candidiasis $(\mathrm{p}=0.008)$ (Table 2). In our final model, no association was observed between WHO clinical stage, HBV status and chronic diarrhoea and PTB-HIV co-infection, respectively, as was seen in the univariate analyses; WHO clinical stage and HBV status remained in the final model as they act as effect modifiers in the independent associations of CD4+ cell count and oropharyngeal candidiasis with PTB-HIV coinfection. The area under the ROC curve for our final model was 0.88 .

\section{Discussion}

In this study, we found a PTB frequency of 9.6\% among HIV-infected adults presenting in our HIV clinic. CD4+ cell count $(\leq 100$ cells $/ \mathrm{mL})$ and oropharyngeal candidiasis were found to be independently associated with PTB-HIV co-infection, with WHO clinical stage and HBV status acting as effect modifiers in multivariate modeling. The area under the ROC curve of 0.88 suggests that the final multivariate model we obtained fitted the data very well and thus helped to confirm the validity of our model.

Bassett et al. reported a PTB-HIV co-infection prevalence of $19 \%$ in Durban, South Africa, which is much higher than our PTB-HIV coinfection frequency of 9.6\% [12]. The global prevalence of PTB-HIV is reported to be $0.18 \%$ [13], which is lower than the $9.6 \%$ for our study. The differences in PTB prevalence rates in other populations compared to ours are likely due to true differences in the burden of TB in these communities.

The association of lower CD4+ cell counts, especially counts $\leq 100$ cells/mL with PTB-HIV co-infection observed in our study is as expected; it is well recognized that the risk of opportunistic infections, including TB, in persons with HIV increases markedly when CD4+ cell counts drops below 200 cells $/ \mathrm{mm}^{3}[3,6,14]$. Depletion of CD4+ $\mathrm{T}$ cells seen in advanced HIV disease impairs host response to $M t b$; particularly granuloma formation hence facilitating progression of recent infection as well as reactivation of latent $\mathrm{TB}$ to active disease [15].This lower CD4+ cell count could also explain our finding of the association between oropharyngeal candidiasis and PTB-HIV coinfection.

Although not statistically significant in the multivariate analysis, there was a trend for increased odds of PTB-HIV co-infection in men despite a preponderance of women in our study. Several studies have shown that male gender was associated with TB-HIV co-infection [16]. This association might further be explained by the $\mathrm{X}$ chromosome susceptibility gene contributing to excess of males with TB in some African populations as suggested by Bellamy et al. [17].

One of the limitations of our study is the small study population; 
Citation: Agbaji O, Ebonyi AO, Meloni ST, Anejo-Okopi JA, Akanbi MO, et al. (2013) Factors Associated With Pulmonary Tuberculosis-HIV Co-Infection in Treatment-Naive Adults in Jos, North Central Nigeria. J AIDS Clin Res 4: 222. doi: 10.4172/2155-6113.1000222

Page 4 of 5

\begin{tabular}{|c|c|c|c|c|}
\hline Predictor & Crude OR $(95 \% \mathrm{Cl})$ & P Value & Adjusted OR ${ }^{\star \star}(95 \% \mathrm{Cl})$ & P Value \\
\hline $\begin{array}{c}\text { Age (yrs) } \\
\quad<34 \\
\geq 34\end{array}$ & $\begin{array}{c}10 \text { (Ref) } \\
0.93(0.38-2.31)\end{array}$ & $\overline{-}$ & $\begin{array}{c}1.00 \text { (Ref) } \\
0.68(0.22-4.26)\end{array}$ & $\overline{-}$ \\
\hline $\begin{array}{l}\text { Sex } \\
\text { Female } \\
\text { Male }\end{array}$ & $\begin{array}{c}1.00 \text { (Ref) } \\
2.17(0.87-5.39)\end{array}$ & 0.096 & $\begin{array}{c}1.00 \text { (Ref) } \\
1.38(0.43-4.26\end{array}$ & 0.60 \\
\hline $\begin{array}{l}\text { Residence } \\
\text { Others } \\
\text { Plateau }\end{array}$ & $\begin{array}{c}1.00 \text { (Ref) } \\
1.84(0.65-5.24)\end{array}$ & $0 . \overline{25}$ & & \\
\hline $\begin{array}{l}\text { Education level } \\
\text { None/ Primary } \\
\text { Secondary/ Tertiary }\end{array}$ & $\begin{array}{c}1.00 \text { (Ref) } \\
1.20(0.45-3.25)\end{array}$ & $\overline{-}$ & & \\
\hline $\begin{array}{l}\text { Occupation } \\
\text { Student } \\
\text { Unemployed } \\
\text { Employed }\end{array}$ & $\begin{array}{c}1.00(\text { Ref }) \\
0.28(0.02-3.36) \\
1.02(0.22-4.78)\end{array}$ & $\begin{array}{l}- \\
0.32 \\
0.98\end{array}$ & & \\
\hline $\begin{array}{l}\text { Marital status } \\
\text { Married } \\
\text { Widowed/Divorced/ Separated } \\
\text { Single }\end{array}$ & $\begin{array}{c}1.00(\text { Ref }) \\
0.64(0.14-2.95) \\
1.18(0.40-3.39)\end{array}$ & $\begin{array}{c}- \\
0.56 \\
0.76\end{array}$ & & \\
\hline $\begin{array}{l}\text { Spouse HIV status } \\
\text { Negative } \\
\text { Positive }\end{array}$ & $\begin{array}{c}1.00 \text { (Ref) } \\
1.93(0.77-4.87)\end{array}$ & - & & \\
\hline $\begin{array}{l}\text { Spouse on ARV } \\
\text { Not on ARV } \\
\text { On ARV }\end{array}$ & $\begin{array}{c}1.00 \text { (Ref) } \\
\text { Predicts failure perfectly* }\end{array}$ & & & \\
\hline $\begin{array}{l}\text { Mode of HIV transmission } \\
\text { Heterosexual } \\
\text { Blood transfusion }\end{array}$ & $\begin{array}{l}0.41(0.04-3.89) \\
1.00(\text { Ref })\end{array}$ & $\begin{array}{c}0.44 \\
-\end{array}$ & & \\
\hline $\begin{array}{l}\text { WHO clinical stage } \\
1 / 2 \\
3 / 4\end{array}$ & $\begin{array}{c}1.00(\text { Ref }) \\
8.68(1.96-38.4)\end{array}$ & 0.004 & $\begin{array}{c}1.00 \text { (Ref) } \\
3.54(0.72-17.42)\end{array}$ & $\overline{-}$ \\
\hline $\begin{array}{l}\text { HBV status } \\
\text { Negative } \\
\text { Positive }\end{array}$ & $\begin{array}{c}1.00 \text { (Ref) } \\
4.4(1.25-15.5)\end{array}$ & $\overline{-} 02$ & $\begin{array}{c}1.00 \text { (Ref) } \\
4.20(0.92-19.12)\end{array}$ & $\overline{-} 06$ \\
\hline $\begin{array}{l}\text { Oropharyngeal candidiasis } \\
\text { Absent } \\
\text { Present }\end{array}$ & $\begin{array}{c}1.00(\text { Ref }) \\
5.27(2.08-13.40)\end{array}$ & $<0.001$ & $\begin{array}{c}1.00 \text { (Ref) } \\
4.56(1.48-14.03)\end{array}$ & $\overline{-} \overline{0}$ \\
\hline $\begin{array}{l}\text { Chronic diarrhoea } \\
\text { Absent } \\
\text { Present }\end{array}$ & $\begin{array}{c}1.00 \text { (Ref) } \\
4.93(1.89-12.85)\end{array}$ & $\overline{-}$ & & \\
\hline $\begin{array}{l}\text { Kaposi's sarcoma } \\
\text { Absent } \\
\text { Present }\end{array}$ & $\begin{array}{c}1.00(\text { Ref }) \\
1.36(0.15(11.60)\end{array}$ & $\overline{-}$ & & \\
\hline $\begin{array}{l}\text { HIV RNA Log viral load (copies } / \mathrm{ml} \text { ) } \\
\quad<5.0 \\
\quad \geq 5.0\end{array}$ & $\begin{array}{c}1.00 \text { (Ref) } \\
2.91(1.17-7.25)\end{array}$ & 0.02 & & \\
\hline $\begin{array}{l}\left.\text { CD4 count (per } \mathbf{~ m m}^{3}\right) \\
\quad \leq 100 \\
\quad>100\end{array}$ & $\begin{array}{c}1.00 \text { (Ref) } \\
0.09(0.03-0.25)\end{array}$ & $<0.001$ & $\begin{array}{c}1.00 \text { (Ref) } \\
0.15(0.05-0.49)\end{array}$ & 0.002 \\
\hline
\end{tabular}

*Stata did not provide the $\mathrm{Cl}$ because there were no subjects on ARV in those without PTB-HIV co-infection

${ }^{* *}$ All predictors with $p<0.20$ were considered for inclusion in the final model. Adjusted ORs for predictors that remained in final model are shown. Chronic diarrhoea and viral load dropped out as significant predictors in the final model.

Table 2: Predictors of PTB-HIV co-infection.

this may explain the loss of association between WHO clinical stage and PTB-HIV co-infection ( $\mathrm{p}=0.06)$ in multivariate analyses, despite this being significant in the univariate analysis $(\mathrm{p}<0.001)$. Another limitation is the generalizability of our study and the observed prevalence; since our study was health facility-based, it is biased towards having a higher prevalence than the general population.

It is expected that most PTB-HIV co-infected patients would have severe immune suppression. In our study, none $(0.0 \%)$ of the patients with PTB-HIV co-infection had a CD4+ cell count above the clinical cut-off value $\left(200 / \mathrm{mm}^{3}\right)$, indicating that all of the co-infected patients were cases of advanced HIV disease that were complicated by PTB. Late presentation of HIV-infected patients in our environment often results in unfavourable clinical outcomes due to a poorer immune recovery following treatment in those with long-standing HIV infection $[18,19]$. In addition, the increased PTB-HIV co-infection in the patients with the most severe HIV disease may increase the risks for further PTB transmission, particularly in hospital settings.

\section{Conclusion}

Pulmonary TB was prevalent among newly diagnosed HIV patients in our setting. Severe immune suppression and oropharyngeal 
Citation: Agbaji O, Ebonyi AO, Meloni ST, Anejo-Okopi JA, Akanbi MO, et al. (2013) Factors Associated With Pulmonary Tuberculosis-HIV Co-Infection in Treatment-Naive Adults in Jos, North Central Nigeria. J AIDS Clin Res 4: 222. doi: 10.4172/2155-6113.1000222

Page 5 of 5

candidiasis were independently associated with PTB-HIV co-infection. Potential implications for severe immune suppression and advanced HIV disease are poor clinical outcomes and further spread of PTB. Strategies to encourage the early diagnosis of both HIV and TB should be considered.

\section{Funding}

This work was funded in part by the US Department of Health and Human Services, Health Resources and Services Administration (U51HA02522). The contents are solely the responsibility of the authors.

\section{Acknowledgement}

We wish to acknowledge the support of APIN Ltd GTE for the care of the patients.

We thank Placid Ugoagwu for data entry and management. We are also grateful to APIN, Jos University Teaching Hospital, Jos for permission to use the data and the Northwestern University AIDS International Training and Research Program (NUAITRP, Grant number 5D43TWOO7995-02) for support towards this manuscript.

\section{References}

1. World Health Organization (2012) Hiv operational plan 2012-2013: Who's support to implement the global health sector strategy on hiv/aids. World Health Organization, Geneva.

2. WHO (2013) Tuberculosis. World Health Organization: Fact sheet $N^{\circ} 104$.

3. Palella FJ Jr, Delaney KM, Moorman AC, Loveless MO, Fuhrer J, et al. (1998) Declining morbidity and mortality among patients with advanced human immunodeficiency virus infection. HIV Outpatient Study Investigators. N Engl J Med 338: 853-860.

4. Bates I, Fenton C, Gruber J, Lalloo D, Lara AM, et al. (2004) Vulnerability to malaria, tuberculosis, and HIVIAIDS infection and disease. Part II: Determinants operating at environmental and institutional level. Lancet Infect Dis 4: 368-375.

5. Batista Jd, de Albuquerque Mde F, Maruza M, Ximenes RA, Santos ML, et al. (2013) Incidence and risk factors for tuberculosis in people living with HIV: cohort from HIV referral health centers in Recife, Brazil. PLoS One 8: e63916.

6. Akanbi MO, Achenbach CJ, Feinglass J, Taiwo B, Onu A, et al. (2013) Tuberculosis after one year of combination antiretroviral therapy in Nigeria: a retrospective cohort study. AIDS Res Hum Retroviruses 29: 931-937.

7. Rutherford ME, Hill PC, Maharani W, Apriani L, Sampurno H, et al. (2012) Risk factors for Mycobacterium tuberculosis infection in Indonesian children living with a sputum smear-positive case. Int J Tuberc Lung Dis 16: 1594-1599.

8. Middelkoop K, Bekker LG, Morrow C, Zwane E, Wood R (2009) Childhood tuberculosis infection and disease: a spatial and temporal transmission analysis in a South African township. S Afr Med J 99: 738-743.

9. Rao VG, Gopi PG, Bhat J, Yadav R, Selvakumar N, et al. (2012) Selected risk factors associated with pulmonary tuberculosis among Saharia tribe of Madhya Pradesh, central India. Eur J Public Health 22: 271-273.

10. Sterling TR, Lau B, Zhang J, Freeman A, Bosch RJ, et al. (2011) Risk factors for tuberculosis after highly active antiretroviral therapy initiation in the united states and canada: Implications for tuberculosis screening. J Infect Dis 204: 893-901.

11. SimÅŸek H, Ceyhan I, Tarhan G, GÃ/4ner U (2010) [Quality assessment of microscopic examination in tuberculosis diagnostic laboratories: a preliminary study]. Mikrobiyol Bul 44: 561-569.

12. Bassett IV, Wang B, Chetty S, Giddy J, Losina E, et al. (2010) Intensive tuberculosis screening for hiv-infected patients starting antiretroviral therapy in durban, south africa. Clin Infect Dis 51: 823-829.

13. Dye C, Scheele S, Dolin P, Pathania V, Raviglione MC (1999) Consensus statement. Global burden of tuberculosis: estimated incidence, prevalence, and mortality by country. WHO Global Surveillance and Monitoring Project. JAMA 282: 677-686.

14. Lawn SD, Badri M, Wood R (2005) Tuberculosis among HIV-infected patients receiving HAART: long term incidence and risk factors in a South African cohort. AIDS 19: 2109-2116.

15. Lawn SD, Butera ST, Shinnick TM (2002) Tuberculosis unleashed: the impact of human immunodeficiency virus infection on the host granulomatous response to Mycobacterium tuberculosis. Microbes Infect 4: 635-646.

16. Holmes CB, Hausler $H$, Nunn $P$ (1998) A review of sex differences in the epidemiology of tuberculosis. Int J Tuberc Lung Dis 2: 96-104.

17. Bellamy R, Beyers N, McAdam KP, Ruwende C, Gie R, et al. (2000) Genetic susceptibility to tuberculosis in Africans: a genome-wide scan. Proc Natl Acad Sci U S A 97: 8005-8009.

18. Adler A, Mounier-Jack S, Coker RJ (2009) Late diagnosis of HIV in Europe: definitional and public health challenges. AIDS Care 21: 284-293.

19. Fisher M (2008) Late diagnosis of HIV infection: major consequences and missed opportunities. Curr Opin Infect Dis 21: 1-3.
Citation: Agbaji O, Ebonyi AO, Meloni ST, Anejo-Okopi JA, Akanbi MO, et al (2013) Factors Associated With Pulmonary Tuberculosis-HIV Co-Infection in Treatment-Naive Adults in Jos, North Central Nigeria. J AIDS Clin Res 4: 222 doi: 10.4172/2155-6113.1000222

This article was originally published in a special issue, Co-infections: HIV handled by Editor(s). Dr. Claudia Goulston, University of Utah, USA
Submit your next manuscript and get advantages of OMICS Group submissions

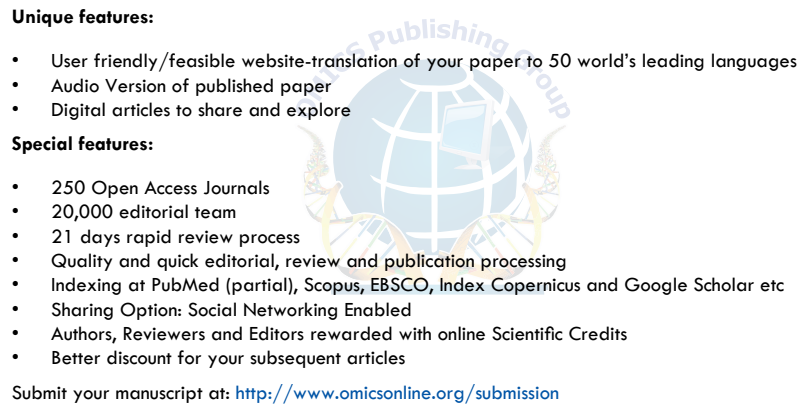

